\title{
Enhancing Microteaching at Sultan Qaboos University
}

\author{
Salma Hamed Al-Humaidi ${ }^{{ }^{*}}$ \& Mohamed Ismail Abu-Rahmah ${ }^{1}$ \\ ${ }^{1}$ Curriculum and Instruction Department, Sultan Qaboos University, Muscat, Oman \\ *Salma Hamed Al-Humaidi, E-mail: shumaidi@squ.edu.om
}

\begin{abstract}
This study was an attempt to maximize the effectiveness of microteaching at SQU. It proposed a model incorporating five components: (1) planning and feedback, (2) teaching and observation, (3) self-assessment and reflection, (4) peers' feedback, and (5) tutor's feedback. The model was applied to a group of 24 student-teachers of English attending the microteaching course at the College of Education, Sultan Qaboos University. To measure the effectiveness of the model, the planning tasks, self-assessment forms, reflective questions raised by peer students, and the tutor's feedback comments were analyzed qualitatively. It was found that the proposed model helped maximize the effectiveness of EFL microteaching at SQU.
\end{abstract}

\section{Keywords}

microteaching, peer-observation, student teachers, effectiveness, reflection, Egypt

\section{Theoretical Background}

Wallace (1991, pp. 87-92), defines microteaching ... as one of a range of techniques for developing "experiential knowledge" of professional action in a controlled and progressive way... [It] denotes a training context in which a teaching situation has been reduced in scope and/or simplified in some systematic way. According to Gower and Waters (1983), microteaching may include teaching a small group of students, either a part of a lesson focusing on specific elements in a limited time. Dunkin and Biddle (1974), Stoddard (1981), McGarvey and Swallow (1986) and Wallace (1991) indicated that the aims of microteaching were different from the aims of the original Stanford University Model (1969) and microteaching is seen as a technique for reflection rather than simply a technique for shaping behavior.

In the literature on reflective teaching (Schon, 1987; Bartlett, 1990; Richards, 1990; Wallace, 1991; Pennington, 1995; Clarke, 1995; Brookfield, 1995; El-Okda, 1998; Farrell, 1998; Stanley, 1998), the term reflection has been defined in different ways implying different approaches to the reflective practice. Brookfield (1995), for example, indicates that in reflective practice, practitioners engage in a continuous cycle of self-observation and self-evaluation in order to understand their own actions and the reactions they prompt in themselves and in learners.

Farrell $(1998$, p. 4) argues that the reflective practice ... is becoming a dominant aspect of ESL/EFL teacher education programs worldwide... [It] refers to teachers subjecting their beliefs and practices of 
teaching to a critical analysis. Wallace (1991) connects microteaching with reflection. However, he does not incorporate any reference to reflection in his 4-stage model of microteaching which includes: the briefing, the teach, the critique, and the reteach. Nor does he propose any tool for helping the trainees to reflect upon what they have done. It is the contention of the current proposed model that reflection is seen as an effective technique for developing the teaching skills of the prospective teachers of English at SQU (Abu-Rahmah \& Al-Humaidi, 2004).

Abundant research provides evidence on the effectiveness of microteaching for pre-service teachers in developing teaching competencies such as English proficiency, planning and English teaching skills, and personality (Ghanaguru, Nair, \& Young, 2013; Remesh, 2013; Ping, 2013; Savas, 2012; Ismail, 2011; Shah \& Masur, 2011; Zakaria, Zarina, \& Ah'hyat, 2010; Karacky \& Sanl1, 2009; Al-Methan, 2003; Akalin, 2005; Benton-Kupper, 2001; MacLeod, 1995; Sahu, 1984), self-efficacy, self-confidence, self-assessment, reflection and professional development (Cetin, 2013; Bulut, 2012; Kavanoz \& Yuksel, 2010; Ogeyik, 2009; Wilkinson, 1996; Amobi, 2005; Abu-Rahmah \& Al-Humaidi, 2004; MacLeod, 1995).

Al-Methan (2003) examined the merits of micro-teaching as perceived by 67 student teachers at Kuwait University using a micro-teaching inventory. The student teachers generally agreed that micro-teaching had positive merits in three main areas; planning skills, personality and teaching competencies.

Cetin (2013) studied the effect of micro-teaching applications on classroom management, self-efficacy convictions of 40 prospective teachers in the academic year 2012-2013. The results proved that micro-teaching applications increased self-efficacy scores of the prospective teachers significantly.

Using both quantitative and qualitative techniques, Ismail (2011) investigates the views of 61 female teachers trainees enrolled in the English language Education Program in the United Arab Emirates. $\mathrm{He}$ proved that prospective teachers acknowledged "the beneficial experiences of microteaching in developing effective instructional strategies" (Ogeyik, 2009).

Using a questionnaire, Savas (2012) investigated the opinions of 40 prospective English as a foreign language (EFL) teachers about the effectiveness of micro-teaching videos in two English language teaching methodology courses at a state university in Turkey. The study shows evidence that micro-teaching videos can enhance English proficiency and English teaching skills.

Still some research showed that microteaching has some limitations such as provoking anxiety and causing stress, big class size, high numbers of students in the class and physical conditions of the setting and lack of interest (Kavanoz \& Yuksel, 2010). There is also lack of opportunities for micro-teaching and practice before going to practicum in schools, lack of close connection between the course materials and practical applications in microteaching class (Cubukcu, 2010) and sense of unreality about microteaching and therefore differences between microteaching and the "real world" of the classroom (Wilson \& I'Anson, 2006). In addition, Lee and Wu (2006) indicated that pre-service teachers have limited opportunities to reflect on their own teaching. Research on micro-teaching 
therefore calls for development of microteaching in teacher training programs. The present study develops a model that focuses on creating opportunities for better feedback and reflection (Abu-Rahmah \& Al-Humaidi, 2004) as well as provoking student teachers' interest.

\subsection{Context of the Problem}

Microteaching is considered an important, practical component of the teacher education program at Sultan Qaboos University. Two courses entitled Methods of Teaching English 1, and 2 are offered at Sultan Qaboos University. Each of these courses involves two parts: the theoretical part and the practical part which is Microteaching.

In the theoretical part, the students learn about the different teaching methods of English and how to teach the four language skills: speaking, reading, writing, and listening. They also focus on teaching grammar, vocabulary, and lesson planning. In the microteaching sessions, student teachers follow a traditional method which includes three main stages: planning, teaching, feedback and discussion. The following is a brief explanation of each of the three stages.

(1) Planning: The teacher trainee plans a short lesson, hands it to their instructor a week before actual teaching, and gets the suggested feedback on it.

(2) Teaching: Supervised by the instructor and peers, the teacher trainee teaches the lesson to the class. During this stage, no comments are received from the instructor or the student-trainees.

(3) Feedback and discussion: On the basis of the observation of the lesson, the instructor leads a discussion with the teacher trainee and peers to give feedback. They reinforce the instances of effective use of the skill and draws attention to the points where the teacher trainee could do to improve their teaching skills. The teacher trainee may plan and teach another lesson focusing on the same aspect or a different one.

\subsection{Problem of the Study}

It was observed that a large number of student teachers of English do not participate effectively in the three stages above. They attend the microteaching classes just for fulfilling the department requirement (Zakaria et al., 2010). This study was an attempt to maximize the effectiveness of microteaching and motivate students to participate effectively in the various tasks and activities conducted in microteaching classes. This purpose was translated into the following two research questions.

(1) What are the components of a proposed model that might maximize the effectiveness of microteaching at SQU?

(2) What is the effectiveness of this model?

\section{Method}

\subsection{Research Design and Participants}

The research design adopted in this study was a two-group post-test design (Seliger \& Shohamy, 1989, p. 145). It included a control group (18 student teachers of English) and an experimental group (24 student teachers). They were attending the Microteaching class at the College of Education. The independent 
variable was represented in the treatment offered using the proposed model. The dependent variable was the performance of student teachers in the microteaching classes.

\subsection{Tools of the Study}

A performance checklist was adapted from another study (Abu Rahmah \& A-Humaidi, 2004) conducted in the Omani context to suit the current study. Before adaptation the checlist included 23 items for measuring the performance of student teachers on practicum. Some items were deleted because they were originally used in a real context, not a simulation context like microteaching. Another important item to do with personality traits (e.g., punctuality, confidence, self-controlling, friendly behavior, positive attitudes towards the language, pupils, and colleagues, etc.) was also deleted from the final analysis because its internal consistency with the total items of the checklist was low.

As shown in Appendix I, the final version of the tool is a 4-point Likert-type checklist including 15 items categorized into: lesson planning, teaching procedures, and other dimensions such as audio visual aids $(\mathrm{AV})$, language proficiency (LP), classroom management $(\mathrm{CM})$ and reflection $(\mathrm{R})$. The four points of the scale are:

$$
\begin{aligned}
& \text { V. Good }=4 \\
& \text { Good }=3 \\
& \text { Satisfactory }=2 \\
& \text { Barely Satisfactory }=1
\end{aligned}
$$

The reliability of the final version of the checklist was .66, using Cronbach's Alpha for measuring the internal consistency. The other two tools were used by the student teachers during their microteaching observation and self-reflection. They were: Microteaching Peer Observation Form (Appendix II) and Microteaching Self-Assessment \& Reflection Form (Appendix III).

\subsection{The Proposed 5-Stage Model}

As shown in the diagram below, a five-component model was proposed. The components of the model are:

(1) Planning and feedback: As done the traditional model, the student teacher is assigned a lesson or mini-lesson to prepare and then s/he gets feedback from their tutor.

(2) Teaching and observation: The student trainee teaches the lesson while the other peers are observing and filling in the observation forms.

(3) Self-assessment and reflection: After teaching, the student teacher is given sometime to self-assess and reflect upon their teaching.

(4) Peers' feedback and reflection: During this phase the other student teachers give their feedback and reflection.

(5) Instructor's feedback: Finally, the instructor wraps up, giving their general feedback comments.

As shown from the five stages of the proposed model, all student teachers are given the chance to work, engage actively and assess the work of their peers. 


\section{Teaching $\&$} Observation

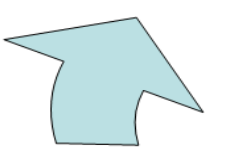

\section{Planning $\&$ Feedback}

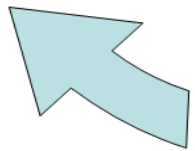

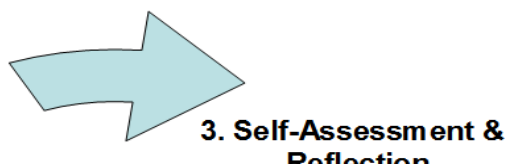

Reflection

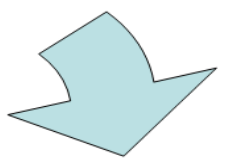

4. Peers' Feedback \&

Reflection

\section{Instructor's} Feedback

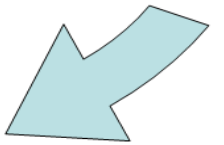

Figure 1. The Proposed 5-Stage Model

\subsection{Procedures}

The proposed model above was applied to the experimental group which included 24 student-teachers of English attending the microteaching practical course at the College of Education, Sultan Qaboos University. The control group (18 student teachers) was taught adopting the traditional method, which, as shown above, includes: planning and feedback, teaching, and feedback and discussion. The developed checklist was used by the instructor to assess the performance of the students in the two groups. Every student in the two groups was given the opportunity to teach and be assessed twice. The two marks were added up in the final analysis.

\subsection{Data Analysis and Findings}

The $t$-test was used to measure the difference between the performance of the control group and experimental group on the scale as a whole. It was also used to measure the difference between the control group and the experimental group on the various dimensions of the checklist: Lesson planning, teaching procedures, and the other dimensions (preparation and use of audio visual aids, language proficiency, classroom management, and reflection). Table (1) below displays the descriptive statistics of these variables.

Table 1. Descriptive Statistics of the Two Groups

\begin{tabular}{lllll}
\hline & Group & $\mathrm{N}$ & Mean & Std. Dev. \\
\hline \multirow{2}{*}{ Lesson planning } & Control & 18 & 19.27 & 2.53 \\
& Experimental & 24 & 21.33 & 1.79 \\
Teaching performance & Control & 18 & 29.33 & 2.30 \\
& Experimental & 24 & 38.67 & 1.74 \\
Other dimensions & Control & 18 & 27.77 & 2.15 \\
\multirow{3}{*}{ Grand Total } & Experimental & 24 & 30.50 & 1.94 \\
& Control & 18 & 76.38 & 4.51 \\
& Experimental & 24 & 90.50 & 3.62 \\
\hline
\end{tabular}


As shown in the table above, there are differences between the performance of the control group students and that of the experimental group students on the four dimensions of the assessment form which are:

(1) The lesson planning dimension,

(2) The teaching performance dimension,

(3) The other dimension, e.g., language proficiency, classroom management,

(4) Use of audio visual aids, and reflection, and

(5) The total items on the checklist.

The students who adopted the proposed model outperformed those who were taught using the traditional model. This result may be displayed clearly by using bar charts for every dimension.

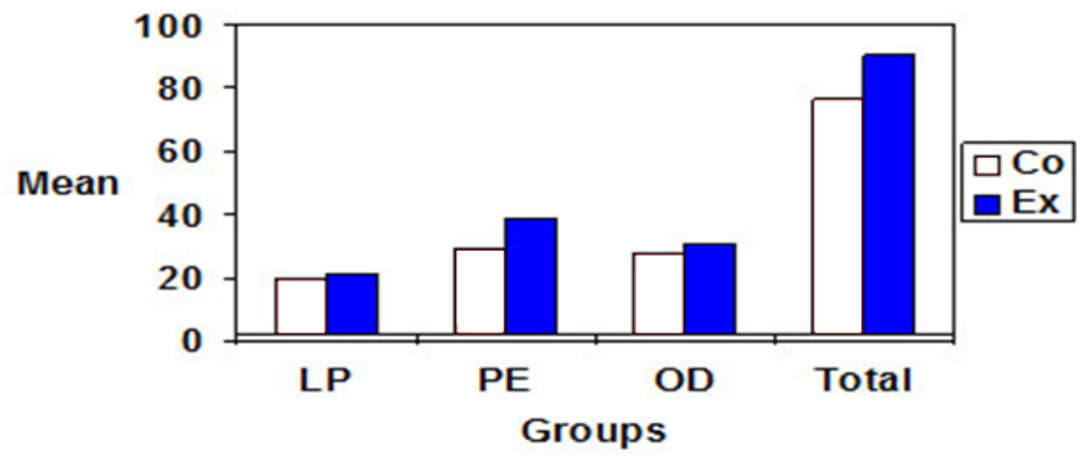

Figure 2. Summary of the Findings

Table (1) above shows the difference between the mean values of the control group (Co) and the experimental group (Ex) on all the dimensions: Lesson planning (LP), performance (PE), the other dimensions (OD) and the total dimensions on the checklist. To check the size of the difference, the $t$-test was used and the results are displayed in Table (2) below.

Table 2. T-Values of the Difference between the Control Group and the Experimental Group on the Three Dimensions of the Scale

\begin{tabular}{lllllll}
\hline & Group & $\mathrm{N}$ & Mean & Std. Dev. & $t$-values & Sig. \\
\hline \multirow{2}{*}{ Lesson planning } & Control & 18 & 19.27 & 2.53 & & .004 \\
& Experimental & 24 & 21.33 & 1.79 & & \\
Teaching performance & Control & 18 & 29.33 & 2.30 & & .08 \\
& Experimental & 24 & 38.67 & 1.74 & & .000 \\
Other dimensions & Control & 18 & 27.77 & 2.15 & & .000 \\
& Experimental & 28 & 30.50 & 1.94 & & \\
Total & Control & 18 & 76.38 & 4.51 & & .000 \\
& Experimental & 24 & 90.50 & 3.62 & & \\
\hline
\end{tabular}


As shown in Table (1) above, there is a statistically significant difference between the performance of the control group students and that of the experimental group students on the four dimensions of the assessment form which are:

(1) The lesson planning dimension (LP),

(2) The teaching performance dimension (PE),

(3) The other dimension, e.g., language proficiency, classroom management, use of audio visual aids, and reflection (OD), and

(4) The total items on the performance checklist.

This means that the students adopted the proposed model outperformed those who were taught using the traditional model. Accordingly, it can be concluded that the proposed model was effective for improving the performance and engagement of student teachers of English in the microteaching sessions. That is, their professional skills in planning, implementation, critical observation, self-assessment and reflection were apparently improved.

\section{Summary and Conclusion}

Microteaching is considered an important, practical component of the ELT teacher education program at Sultan Qaboos University, Oman. However, it was observed that a large number of ELT student teachers did not participate effectively in the microteaching classes. They attended the classes just for fulfilling the department requirement. This study was an attempt to maximize the effectiveness of the ELT microteaching classes and motivate ELT student teachers to participate effectively in the various tasks and activities conducted in the ELT microteaching classes at SQU.

Towards this end, a five-component model was proposed. The components of the model were: (1) planning and feedback, (2) teaching and peer observation, (3) self-assessment and reflection, (4) peers' feedback and reflective questions, and (5) instructor's feedback. In order to implement this model effectively, three tools were developed, validated and used in the microteaching sessions. These tools were: (1) an instructor's performance assessment form, (2) a self-assessment and reflection form, and (3) a peer observation form.

In order to try out the model, two groups of ELT student teachers participated in this study. One of the groups was considered the experimental group and it included 24 student teachers of English (4th level) at the College of Education (SQU). The second was the control group and it included 18 student teachers of the same major and academic level. The proposed model was applied to the experimental group, whereas the control group was taught adopting the 3-stage traditional model (planning, implantation and discussion). For measuring the effectiveness of the proposed model, every student teacher in the two groups was given the opportunity to teach and be assessed twice, using the instructor's performance assessment form developed for that purpose. The $t$-test was applied to compare the performance of the two groups. It was found that there was a statistically significant difference between the performance of the control group students and that of the experimental group 
students on the four dimensions of the assessment form. The ELT student teachers in the experimental group who adopted the proposed model outperformed the ELT student teachers in the control group who were taught using the traditional model.

Accordingly, it was concluded that the proposed model was effective for improving the performance and involvement of the ELT student teachers in the microteaching classes. That is, their professional skills in planning, implementation, critical observation, self-assessment and reflection were apparently improved. The study provided support to previous research that shows evidence on the effectiveness of microteaching on these aspects (Ghanaguru et al., 2013; Remesh, 2013; Ping, 2013; Savas, 2012; Ismail, 2011; Shah \& Masur, 2011; Zakaria et al., 2010; Karacky \& Sanl1, 2009; Al-Methan, 2003; Akalin, 2005; Benton-Kupper, 2001; MacLeod, 1995; Sahu, 1984; Cetin, 2013; Bulut, 2012; Kavanoz \& Yuksel, 2010; Ogeyik, 2009; Wilkinson, 1996; Amobi, 2005; Abu-Rahmah \& Al-Humaidi, 2004; MacLeod, 1995).

In the light of these findings, some recommendations were given. These were: (1) the suggested model should be applied to all ELT microteaching student teachers and to the other majors in the Dept. of Curriculum and Instruction, (2) the model should be used in teaching practice as well. The ELT student teachers can be provided with peer observation forms, self-assessment and reflection forms. They can also be involved in their professional development process. However, two further studies are still needed. These studies are: (1) investigating the attitudes and perceptions of the ELT student teachers as regards the proposed model and (2) investigating the effect of the proposed model on the actual performance of the ELT student teachers in the classroom during teaching practice.

\section{References}

Abu, R. M., \& Al-Humaidi, S. (2004). An Integrative 5-stage model for Maximizing the effectiveness of The teaching practice program at SQU. Third Educational Conference, College of Education, Sultan Qaboos University.

Akalin, S. (2005). Comparison between traditional teaching and microteaching during school experience of student-teachers. Eurasian Journal of Education Research, 20, 1-13.

Al-Methan, A. E. (2003). Merits of Micro-teaching as Perceived by Student Teachers at Kuwait University. Journal Pendidikan, 28, 65-76.

Amobi, F. A. (2005). Preservice Teachers' Reflectivity on the Sequence and Consequences of Teaching Actions in a Microteaching Experience. Teacher Education Quarterly, 32(1), 115-130.

Bartlett, L. (1990). Teacher development through reflective teaching. In J. C. Richards, \& D. Nunan (Eds.), Second Language Teacher Education. New York: Cambridge University Press.

Benton-Kupper, J. (2001). The microteaching experience: Student perspectives. Education, 121, 830-835.

Brookfield, S. (1995). Becoming a Critically Reflective Teacher. San Francisco: Jossey-Bass.

Bulut, M. (2012). Attititudes of Junior and Senior Students towards Microteaching in English language 
Teaching Department at Mersin University. Procedia-Social and Behavioral Sciences, 55, 730-738.

Cetin, S. (2013). The effect of micro-teaching applications that are used in teaching practice course on classroom management self-efficacy convictions of students. International Journal of Academic Research Part B, 5(4), 375-379.

Clarke, A. (1995). Professional development in practical settings: Reflective practice under scrutiny. Teaching and Teacher Education, 11, 243-261.

Dunkin, M. J., \& Biddle, B. J. (1974). The Study of Teaching. London: University Press of America.

El-Okda, M. (1998). A portfolio-based programme for developing student teachers' disposition to teach English reflectively. Journal of Educational Sciences, 12.

Farrell, T. (1998). Unravelling reflective teaching. TESL Reporter, 31(2), 1-10.

Ghanagura, S., Nair, P., \& Young, C. (2013). Teacher Trainers' Beliefs in microteaching and lesson planning in a teacher training institution. The English Teacher, 42(2), 104-116.

Gower, R., \& Walters, S. (1983). Teaching Practice Handbook. Oxford: Heinemann.

Ismail, S. A. A. (2011). Student Teachers' microteaching experiences in a pre-service English teacher education program. Journal of Language Teaching and Research, 2(5), 1043-1051.

Karackay, A. T., \& Sanl1, S. (2009). The effect of micro teaching application on the preservice teachers' teacher competency levels. Procedia Social and Behavioral Sciences, 1, 844-847.

Kavanoz, H. S., \& Yuksel, G. (2010). An Investigation of peer-teaching technique in student teacher development. The International Journal of Research in Teacher Education, 1(special issue), 1-19.

Lee, G. C., \& Wu, C. (2006). Enhancing the teaching experience of pre-service teachers through the use of videos in web-based computer mediated communication (CMC). Innovation in Education and Teaching Intervention, 43(4), 369-380.

MacLeod, G. (1995). Microteaching in Teacher Education. In L. W. Anderson (Ed.), International Encyclopedia of Teaching and Teacher Education (pp. 573-715). Oxford Pergamon Press.

McGarvey, B., \& Swallow, D. (1986). Microteaching in Teacher Education and Training. London: Croom Helm.

Ogeyik, M. C. (2009). Attitudes of the Student Teachers in English language teaching programs towards microteaching technique. Canadian Center of Science Education (CCSE), 2(3), 205-213.

Pennington, M. C. (1995). The teacher change cycle. TESOL Quarterly, 29(4), 705-731.

Ping, W. (2013). Microteaching: A powerful tool to embedding the English teacher certification testing in the development of English teaching methodologies. International Journal of English Language and Literature Studies, 2(3), 163-175.

Remesh, A., \& Memorial, S. (2013). Microteaching, and efficient technique for learning effective teaching. Journal of Research in Medical Sciences, 18(2), 158-163.

Richards, J. C. (1990). Beyond training: Approaches to teacher education in language teaching. Language Teacher, 14(2), 3-8. 
Sahu, A. R. (1984). Microteaching: Some research studies and research questions. International Journal of Mathematical Education in Science and Technology, 5(6), 727-735.

Savas, P. (2012). Micro-Teaching videos in EFL Teacher Education methodology courses: Tools to enhance English proficiency and teaching skills among trainees. Procedia-Social and Behavioral Sciences, 55, 730-738.

Schon, D. A. (1987). Educating the Reflective Practitioner: Towards a New Design for Teaching and Learning in the Profession. San Francisco: Jossey-Bass Publishers.

Seliger, H., \& Shohamy, E. (1989). Second Language Research Methods. Oxford: Oxford University Press.

Shah, S. M. H., \& Masrur, R. (2011). Impact of micro teaching skills on the performance of primary school teachers. Gomal University Journal of Research, 27(1), 15-29.

Stanley, C. (1998). A framework for teacher reflectivity. TESOL Quarterly, 32(3), 584-591.

Stoddart, J. (1981). Microteaching: Current Practice in Britain with Special Reference to ESOL. London: University of London, Institute of Education.

Wallace, M. J. (1991). Training Foreign Language Teacher. Cambridge University Press.

Wilkinson, G. A. (1996). Enhancing microteaching through additional feedback from preservice administrators. Teaching and Teacher Education, 12(2), 211-221.

Wilson, G., \& I'Anson, J. (2006). Reframing the practicum: Constructing performative space in initial teacher education. Teaching and Teacher Education, 22, 353-361.

Zakaria, W., Zarina, W., \& Ah'hyat, N. (2010). A Study on microteaching as perceived by UTM TESL undergraduates. University Teknologi Malaysia. 


\section{Appendix I}

Microteaching Instructor's Assessment Form

Sultan Qaboos University

Curriculum and Instruction Dept.

Date:

Student teacher's name:

Key: $\quad V G=V$. Good

$\mathrm{St}=$ Satisfactory
College of Education

English Pedagogy Unit

Section

$\mathrm{G}=\mathrm{Good}$

$\mathrm{BS}=$ Barely Satisfactory

\begin{tabular}{|c|c|c|c|c|c|}
\hline & \multicolumn{5}{|l|}{ Lesson Planning } \\
\hline 1. & Identifying *SMART objectives for the lesson & VG & $\mathrm{G}$ & $\mathrm{S}$ & BS \\
\hline 2. & $\begin{array}{l}\text { The planned tasks and activities match the objectives of the lesson and } \\
\text { proceed logically and in an organized way. }\end{array}$ & VG & G & $\mathrm{S}$ & BS \\
\hline \multirow[t]{2}{*}{3.} & $\begin{array}{l}\text { Incorporating the necessary components of a lesson plan, e.g., } \\
\text { evaluation, supporting materials, assignment. }\end{array}$ & VG & G & $\mathrm{S}$ & BS \\
\hline & \multicolumn{5}{|l|}{ Teaching Procedures and Activities } \\
\hline 4. & Giving clear instructions for tasks and activities & VG & $\mathrm{G}$ & $\mathrm{S}$ & BS \\
\hline 5. & Using pair and/or group work & VG & $\mathrm{G}$ & $\mathrm{S}$ & BS \\
\hline 6. & Involving all students & VG & G & $\mathrm{S}$ & BS \\
\hline 7. & Reinforcing students' answers and participation & VG & $\mathrm{G}$ & $\mathrm{S}$ & $\mathrm{BS}$ \\
\hline 8. & Dealing with students' errors & VG & $\mathrm{G}$ & $\mathrm{S}$ & BS \\
\hline \multirow[t]{2}{*}{9.} & Applying a variety of methods/techniques & VG & $\mathrm{G}$ & $\mathrm{S}$ & BS \\
\hline & \multicolumn{5}{|l|}{ Preparation and Use of Audio-visual Aids/Multimedia } \\
\hline \multirow[t]{2}{*}{10.} & $\begin{array}{l}\text { Using the whiteboard, preparing and/or using other audio-visual } \\
\text { aids/multimedia }\end{array}$ & VG & G & $\mathrm{S}$ & BS \\
\hline & \multicolumn{5}{|l|}{ Language Proficiency } \\
\hline 11. & Fluency and accuracy of oral explanation, questions and examples & VG & $\mathrm{G}$ & $\mathrm{S}$ & BS \\
\hline 12. & Accuracy of written examples and questions & VG & $\mathrm{G}$ & $\mathrm{S}$ & $\mathrm{BS}$ \\
\hline 13. & $\begin{array}{l}\text { Classroom management: Control and discipline in class, maintaining } \\
\text { good eye contact while explaining and/or writing on the board }\end{array}$ & VG & G & $\mathrm{S}$ & BS \\
\hline 14. & $\begin{array}{l}\text { Personal traits (e.g., punctuality, confidence, self-controlling, friendly } \\
\text { behavior, positive attitudes towards the language, pupils, and } \\
\text { colleagues, etc.) }\end{array}$ & VG & G & $\mathrm{S}$ & BS \\
\hline 15. & $\begin{array}{l}\text { Self-Assessment and Reflection: Reflecting on his/her teaching to } \\
\text { identify the good aspects and the aspects that need improvement }\end{array}$ & VG & G & $\mathrm{S}$ & BS \\
\hline \multicolumn{6}{|c|}{ Total Grade } \\
\hline \multicolumn{6}{|c|}{ Any other comments } \\
\hline \multicolumn{6}{|l|}{1.} \\
\hline 2. & & & & & \\
\hline
\end{tabular}

Instructor: 


\section{Appendix II}

Microteaching Peer Observation Form

Date: / /

Section

Student teacher's name:

Observer's name:

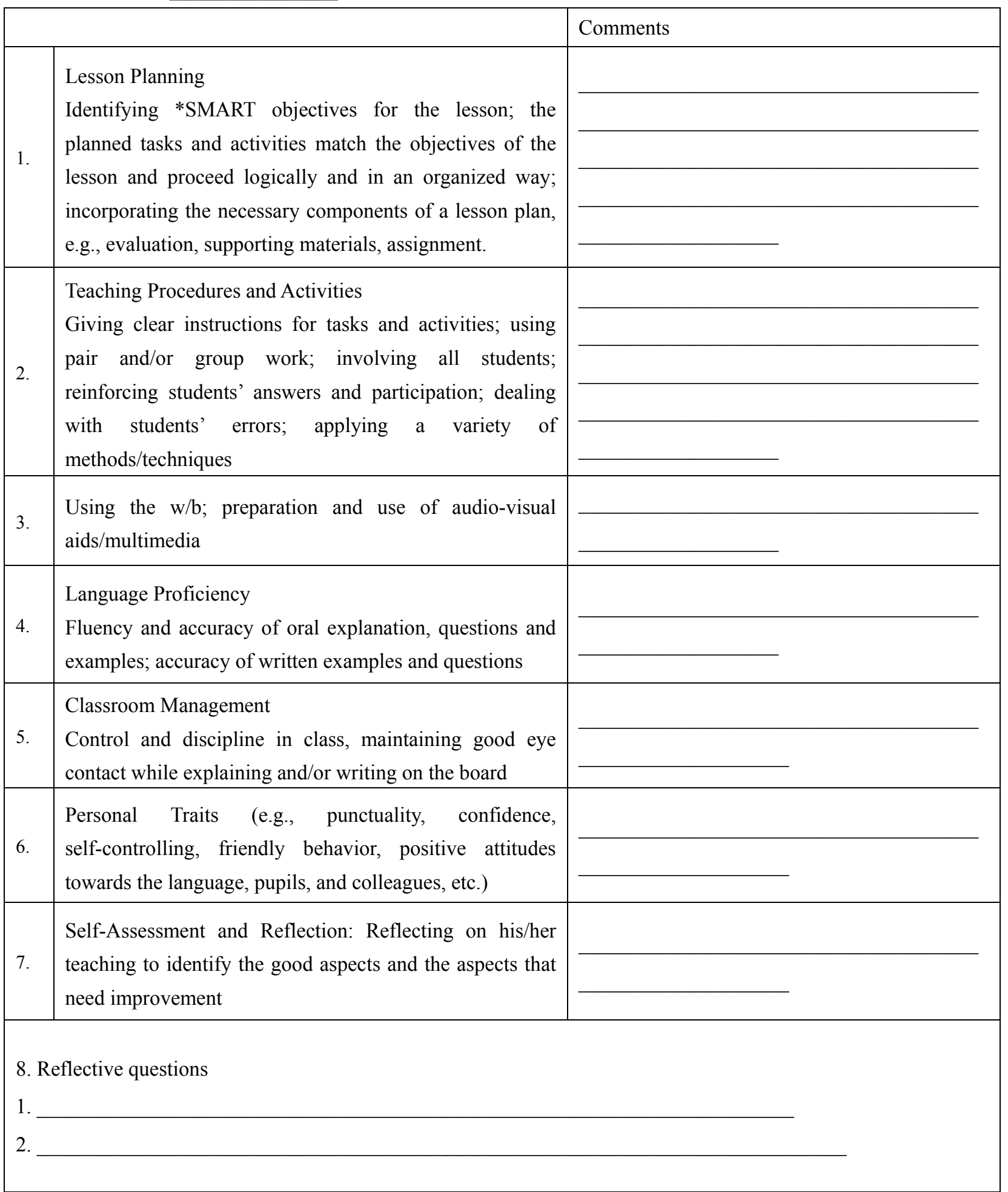




\section{Appendix III}

Microteaching Self-Assessment and Reflection Form

Date: / /

Section

Student teacher's name:

Key: $\quad \mathrm{VG}=\mathrm{V}$. Good

$\mathrm{G}=\mathrm{Good}$

$\mathrm{St}=$ Satisfactory

BS $=$ Barely Satisfactory

\begin{tabular}{|l|l|l|l|l|l|}
\hline 1. & Lesson Planning & VG & G & St & Bs \\
\hline 2. & Teaching procedures and activities & VG & G & St & Bs \\
\hline 3. & Preparation and use of audio-visual aids/multimedia & VG & G & St & Bs \\
\hline 4. & Language proficiency & VG & G & St & Bs \\
\hline 5. & Classroom management & VG & G & St & Bs \\
\hline 6. & Personal traits (e.g. Punctuality, confidence, self-controlling, etc.) & VG & G & St & Bs \\
\hline
\end{tabular}

7. If you are asked to teach this mini-lesson in another class, are you going to use the same plan and repeat the same procedures?

Yes, why?

No, why not? 